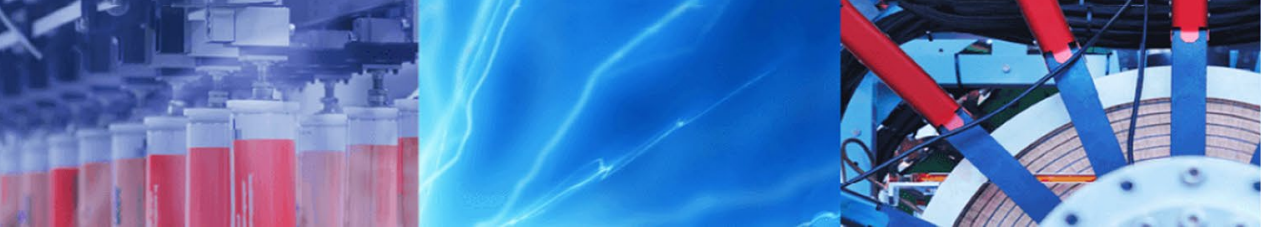

Research Article

\title{
Synthesis, experimental and theoretical antiradical activity assessment of some azomethines and phenylhydrazones
}

\author{
Rafik Bensegueni $^{1,2} \cdot$ Mounia Guergouri $^{2} \cdot$ Chawki Bensouici $^{3} \cdot$ Mustapha Bencharif $^{2}$
}

(c) Springer Nature Switzerland AG 2018

\begin{abstract}
A set of four azomethines and two phenylhydrazones, labeled SIM, SIF, SIT, SIC, SIP and NIP, were synthesized. Afterward, they were subjected to antiradical activity tests (DPPH, CUPRAC and reducing power). Moreover, molecular modeling calculations at the density functional theory level were carried out on these molecules to determine some thermodynamic molecular descriptors (BDE, IP, PDE, PA and ETE) to analyze and explain the corresponding experimental results. Antiradical activity tests were very fulfilling showing a well-established antiradical power for the studied compounds especially in the case of CUPRAC assay in which all of our molecules show a more or less pronounced activity with NIP and SIP in top positions, displaying an $A_{0.5}$ values of $3.09 \pm 0.08 \mu \mathrm{g} / \mathrm{mL}$ and $4.26 \pm 0.44 \mu \mathrm{g} / \mathrm{mL}$, respectively. These values are inferior to those of the used standard antioxidants; butylated hydroxyanisole (BHA) and butylated hydroxytoluene (BHT). The NIP compound exhibits the highest DPPH scavenging activity, followed by SIP, which was even greater than that of $\mathrm{BHA}$ and $\mathrm{BHT}$, with an $\mathrm{IC}_{50}$ of $3.81 \pm 0.26$ against $6.14 \pm 0.41$ and $12.99 \pm 0.41 \mu \mathrm{g} / \mathrm{mL}$, respectively. The resulting molecular descriptors values and the calculated properties are in a good agreement with the experimental results. Therefore, the attained findings showed an excellent correlation between theoretical and experimental studies, jointly confirming the antiradical power of our compounds, which could allow them to be used in pharmaceutical or in food industries.
\end{abstract}

Keywords Azomethines · Phenylhydrazones · Antiradical activity · DFT calculations

\section{Introduction}

The antiradical compounds searching, continues to attract interest of scientists and industrial actors from pharmaceutical to food industries. Azomethines or Schiff bases, are compounds characterized by a structure of the form $R N=C R^{\prime} R^{\prime \prime}$, that have been widely studied. Their antiradical activity was investigated and demonstrated in several works $[2,23]$. Schiff bases can also form with metal ions very interesting complexes with biological activities $[6,25,28,32]$. Phenolic Schiff bases in particular, constitute a class of drugs for oxidative stress diseases [11]. Phenylhydrazones are compounds that contain a $\mathrm{Ph}-\mathrm{NH}-\mathrm{N}=\mathrm{CH}-\mathrm{Ph}$ group in their structures. Antiradical activity of phenylhydrazones and their derivatives was established in various studies $[17,31]$. Other applications of these compounds have been cited in some articles in a wide range of fields. Thus, they are found as conductive polymers [15], or fluorescence sensors [19], or as catalysts [12]. Theoretical studies on this compounds kind are found in literature trying to make a structure-properties relationship and to correlate experimental findings to theoretical ones $[9,24]$.

In this work, a set of four azomethines and two phenylhydrazones were synthesized (Fig. 1), characterized with ${ }^{1} \mathrm{H}$ NMR and then subjected to three antiradical activity tests namely, DPPH scavenging activity test, cupric reducing antioxidant capacity test (CUPRAC) and ferric reducing

\footnotetext{
$\triangle$ Mustapha Bencharif, m_bencharif@umc.edu.dz|'niversité Mohamed Cherif Messaadia, 41000 Souk Ahras, Algeria. ${ }^{2}$ Laboratoire de Chimie des Matériaux Constantine, Université des frères Mentouri Constantine 1, 25000 Constantine, Algeria. ${ }^{3}$ Centre de Recherche en Biotechnologie, Ali Mendjeli Nouvelle ville UV03, Constantine, Algeria.
} 


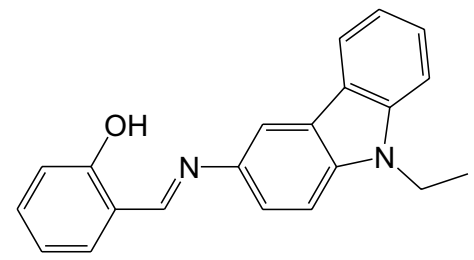

SIC

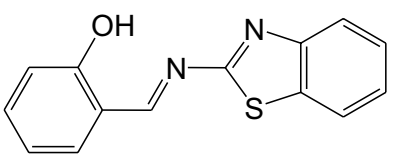

SIT

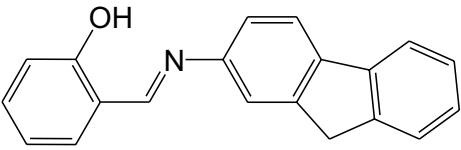

SIF

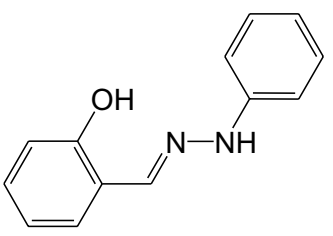

SIP<smiles>Oc1ccccc1/C=N/c1nc2ccccc2[nH]1</smiles>

SIM

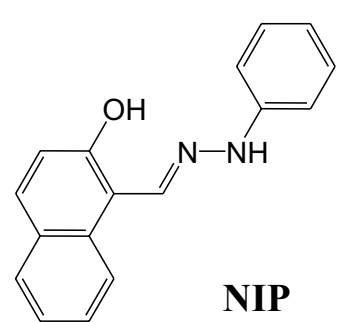

Fig. 1 Chemical structures of the studied compounds (azomethines: SIC, SIF, SIM and SIT, phenylhydrazones: SIP and NIP)

antioxidant power test (FRAP). Throughout this article, our six compounds will be labeled SIC, SIF, SIM and SIT for azomethines and SIP and NIP for phenylhydrazones. The theoretical part of this study relates to the calculation of some thermodynamic molecular descriptors of the tested molecules, with the density functional theory (DFT). The comparison of these descriptors allows proposing the most favorable mechanism for the free radicals scavenging activity. Hence, three mechanisms that may coexist could be observed. The first one is called hydrogen atom transfer (HAT), the second one is known as single electron transfer-proton transfer (SET-PT) and the third mechanism is the sequential proton loss electron transfer (SPLET) [20, 21]. The following equations illustrate the cited mechanisms:

HAT $: R X-H \rightarrow H^{*}+R X$.

$\mathrm{SET}-\mathrm{PT}:\left\{\begin{array}{c}R X-H \rightarrow(R X-H)^{+\cdot}+e^{-} \\ (R X-H)^{+\cdot} \rightarrow R X \cdot+H^{+}\end{array}\right.$

SPLET : $\left\{\begin{array}{c}R X-H \rightarrow R X^{-}+H^{+} \\ R X^{-} \rightarrow R X+e^{-}\end{array}\right.$

Each mechanism is characterized by one or more descriptors such as for HAT which is related to the $\mathrm{O}-\mathrm{H}$ bond dissociation enthalpy (BDE). The first step of the SET-PT mechanism is controlled by the ionisation potential (IP) while the second step is governed by the proton dissociation enthalpy (PDE) of the corresponding cationradical. Finally, for the SPLET mechanism, the proton affinity (PA) of the anion $\mathrm{RX}^{-}$and the electron transfer enthalpy (ETE) are the enthalpies that manage the two steps of the mechanism, respectively. Therefore, BDE, IP and PA are the main molecular descriptors which determine the preferred antiradical mechanism. The lower are their values, the higher is the activity.

CUPRAC and reducing power tests mechanism consists of an electron transfer from the studied molecule to the copper(II) complex and the iron(III) complex [4], respectively. That's why CUPRAC and reducing power activities are related to the IP value of the tested compound, the higher is the IP value, the lower is the antiradical activity.

Other properties as molecular orbital energies or spin density distributions, that permit to analyze and explain the obtained experimental results were calculated.

\section{Materials and methods}

\subsection{Materials}

For synthesis: Salicylaldehyde, 3-amino-9-ethylcarbazole, 2-aminofluorene, 2-aminobenzimidazole, 2-aminobenzothiazole, 2-hydroxy-1-naphthaldehyde, phenylhydrazine hydrochloride, sodium acetate and absolute ethanol were obtained from Sigma-Aldrich. All products were used without further purification.

For antiradical tests: 1,1-diphenyl-2-picrylhydrazyl (DPPH), butylated hydroxyanisole (BHA), butylated hydroxytoluene (BHT), neocuproine, trichloroacetic acid (TCA), potassium ferricyanide $\left(\mathrm{K}_{3} \mathrm{Fe}(\mathrm{CN})_{6}\right)$, were obtained from Sigma Chemical Co. (Sigma-Aldrich $\mathrm{GmbH}$, Sternheim, Germany), iron (III) chloride $\left(\mathrm{FeCl}_{3}\right)$, copper (II) chloride $\left(\mathrm{CuCl}_{2}\right)$, ammonium acetate $\left(\mathrm{ACNH}_{4}\right)$ were obtained from Biochem Chemopharma. All other chemicals and solvents were of analytical grade. 
All calculations were performed with GAUSSIAN 09 software [14], while GaussView 5.0.9 [13] was used for results visualization and analysis.

${ }^{1} \mathrm{H}$ NMR spectra were recorded on a Bruker Avance DPX 250 spectrometer with TMS as internal reference. Measurements and calculations of the antiradical activity were carried out on a 96-well microplate reader, Perkin Elmer Multimode Plate Reader EnSpire.

\subsection{Synthesis}

Azomethines (SIC, SIF, SIM and SIT) were synthesized by a condensation between salicylaldehyde and the corresponding amine in ethanolic medium [18]. A solution containing salicylaldehyde $(5.2 \mathrm{mmol})$ and amine $(5.2 \mathrm{mmol})$ in ethanol $(12 \mathrm{~mL})$, was refluxed for $1 \mathrm{~h}$ and cooled to $5^{\circ} \mathrm{C}$. The resulting precipitate was collected by filtration and washed with cold ethanol (Scheme 1).

Identification of 2-((E)-(9-ethyl-9H-carbazol-7-ylimino)methyl) phenol (SIC) Yellow powder, yield: $65 \%$. M.p.: $114{ }^{\circ} \mathrm{C} .{ }^{1} \mathrm{H}$ RMN $\left(\mathrm{CDCl}_{3}, 250 \mathrm{MHz}\right): 11.75(\mathrm{~s}, 1 \mathrm{H},-\mathrm{OH}) ; 8.8(\mathrm{~s}, 1 \mathrm{H},-$ $\mathrm{CH}=\mathrm{N}-) ; 8.22(\mathrm{~d}, 1 \mathrm{H}, \mathrm{J}=7.77 \mathrm{~Hz}) ; 8.09(\mathrm{~d}, 1 \mathrm{H}, \mathrm{J}=1.93 \mathrm{~Hz})$; 7.56-7.43 (m, 4H); $7.37(\mathrm{~d} ; 1 \mathrm{H}, \mathrm{J}=8.5 \mathrm{~Hz}) ; 7.28(\mathrm{t}, 1 \mathrm{H}$, $\left.\mathrm{J}_{1}=8.11 \mathrm{~Hz}, \mathrm{~J}_{2}=6.57 \mathrm{~Hz}\right) ; 7.09(\mathrm{~d}, 1 \mathrm{H}, \mathrm{J}=7.97 \mathrm{~Hz}) ; 6.98(\mathrm{t}$, $\left.1 \mathrm{H}, \mathrm{J}_{1}=7.36 \mathrm{~Hz}, \mathrm{~J}_{2}=7.46 \mathrm{~Hz}\right) ; 4.42\left(\mathrm{q}, 2 \mathrm{H}, \mathrm{CH}_{2}, \mathrm{~J}=7.22 \mathrm{~Hz}\right)$; $1.47\left(\mathrm{t}, 3 \mathrm{H}, \mathrm{CH}_{3}, \mathrm{~J}=7.22 \mathrm{~Hz}\right)$.

Identification of 2-((E)-(9H-fluoren-7-ylimino)methyl)phenol (SIF) Yellow powder, yield: $70 \%$. M.p.: $160{ }^{\circ} \mathrm{C} .{ }^{1} \mathrm{H}$ RMN
$\left(\mathrm{CDCl}_{3}, 250 \mathrm{MHz}\right): 13.5(\mathrm{~s}, 1 \mathrm{H},-\mathrm{OH}) ; 8.8(\mathrm{~s}, 1 \mathrm{H},-\mathrm{CH}=\mathrm{N}-)$; $7.86(\mathrm{~d}, 1 \mathrm{H}, \mathrm{J}=7.87 \mathrm{~Hz}) ; 7.82(\mathrm{~s}, 1 \mathrm{H}) ; 7.6-7.34(\mathrm{~m}, 7 \mathrm{H}) ; 7.08$ $(\mathrm{d}, 1 \mathrm{H}, \mathrm{J}=8.13 \mathrm{~Hz}) ; 7\left(\mathrm{t}, 1 \mathrm{H}, \mathrm{J}_{1}=7.04 \mathrm{~Hz} ; \mathrm{J}_{2}=7.47 \mathrm{~Hz}\right) ; 3.9$ $\left(\mathrm{s}, 2 \mathrm{H}, \mathrm{CH}_{2}\right)$.

Identification of 2-((E)-(1H-benzoimidazol-2-ylimino)methyl) phenol (SIM) Yellow powder, yield: $94 \%$. M.p.: $205^{\circ} \mathrm{C}$. ${ }^{1} \mathrm{H}$ RMN $\left(\mathrm{CDCl}_{3}, 250 \mathrm{MHz}\right): 12.4(\mathrm{~s}, 1 \mathrm{H},-\mathrm{OH}) ; 9.6(\mathrm{~s}, 1 \mathrm{H},-$ $\mathrm{CH}=\mathrm{N}-) ; 7.8(\mathrm{~s}, 1 \mathrm{H}, \mathrm{NH}) ; 7.55-7.46(\mathrm{~m}, 4 \mathrm{H}) ; 7.34(\mathrm{~d}, 1 \mathrm{H}$, $\mathrm{J}=6.02 \mathrm{~Hz}) ; 7.31(\mathrm{~d}, 1 \mathrm{H}, \mathrm{J}=5.98 \mathrm{~Hz}) ; 6.95-7.1(\mathrm{~m}, 2 \mathrm{H})$.

Identification of 2-((E)-(benzothiazol-2-ylimino)methyl)phenol (SIT) Yellow powder, yield: $34 \%$. M.p.: $108-110^{\circ} \mathrm{C} .{ }^{1} \mathrm{H}$ RMN $\left(\mathrm{CDCl}_{3}, 250 \mathrm{MHz}\right): 12.3(\mathrm{~s}, 1 \mathrm{H},-\mathrm{OH}) ; 9.33(\mathrm{~s}, 1 \mathrm{H},-\mathrm{CH}=\mathrm{N}-)$; $8.02(\mathrm{~d}, 1 \mathrm{H}, \mathrm{J}=8.02 \mathrm{~Hz}) ; 7.89(\mathrm{~d}, 1 \mathrm{H}, \mathrm{J}=7.33 \mathrm{~Hz}) ; 7.37-7.55$ $(\mathrm{m}, 2 \mathrm{H}) ; 7.01-7.15(\mathrm{~m}, 4 \mathrm{H})$.

The phenylhydrazones compounds (SIP and NIP) were synthesized by the action of the hydrochloride of phenylhydrazine on an aldehyde in acetate medium (Scheme 2).

To an equimolar mixture $(0.025 \mathrm{~mol})$ of phenylhydrazine hydrochloride $\mathrm{NH}_{2} \mathrm{NHPh}, \mathrm{HCl}$ and sodium acetate $\mathrm{CH}_{3} \mathrm{COONa}$, dissolved in water, was added $0.02 \mathrm{~mol}$ of the carbonyl compound which is placed in ethanol. Afterwards, the mixture was refluxed. In the colloidal solution, the precipitate was gradually formed, filtered, and strongly washed with distilled water.

Identification of 2-hydroxy-1-naphthaldehyde phenylhydrazone (NIP) Yellow powder, yield: $75 \%$. M.p.: $205-208{ }^{\circ} \mathrm{C}$.

Scheme 1 Synthesis scheme of azomethine compounds<smiles></smiles>

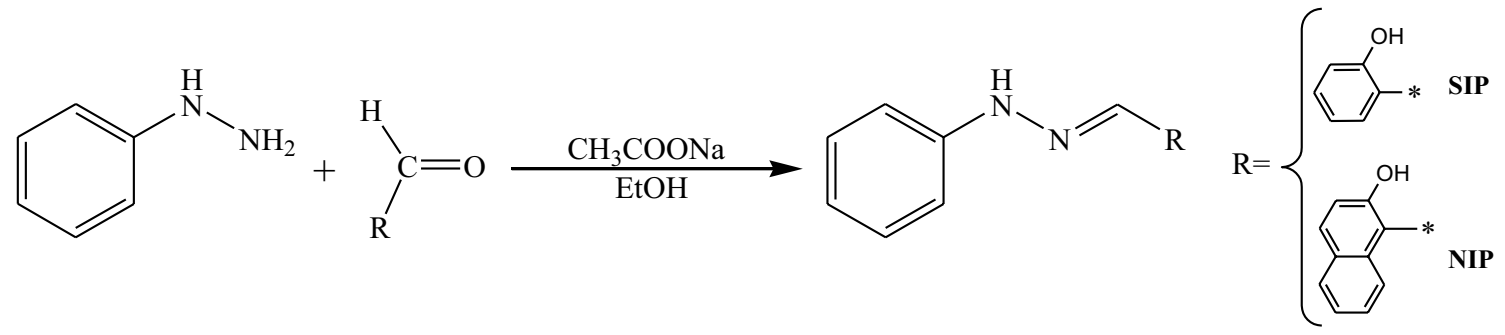

Scheme 2 Synthesis scheme of phenylhydrazone compounds 
${ }^{1} \mathrm{H}$ RMN (DMSO, $\left.250 \mathrm{MHz}\right): 12.25(\mathrm{~s}, 1 \mathrm{H}, \mathrm{OH}) ; 8.88(\mathrm{~s}, 1 \mathrm{H}$, $\mathrm{CH}=\mathrm{N}) ; 7.97(\mathrm{~d}, 1 \mathrm{H}, \mathrm{J}=8.6 \mathrm{~Hz}) ; 7.69(\mathrm{~d}, 1 \mathrm{H}, \mathrm{J}=8 \mathrm{~Hz}) ; 7.63$ $(\mathrm{d}, 1 \mathrm{H}, \mathrm{J}=8 \mathrm{~Hz}) ; 7.41(\mathrm{t}, 1 \mathrm{H}, \mathrm{J}=8.31 \mathrm{~Hz}) ; 7.1-7.28(\mathrm{~m}, 4 \mathrm{H})$; $6.94(\mathrm{~d}, 2 \mathrm{H}, \mathrm{J}=7.6 \mathrm{~Hz}) ; 6.78(\mathrm{t}, 2 \mathrm{H}, \mathrm{J}=7.31 \mathrm{~Hz})$.

Identification of salicylaldehyde phenylhydrazone (SIP) Yellow powder, yield: $81 \%$. M.p.: $141-142{ }^{\circ} \mathrm{C} .{ }^{1} \mathrm{H}$ NMR $\left(\mathrm{CDCl}_{3}\right.$, $250 \mathrm{MHz}$ ): 10.92 (s, 1H, OH); $7.98(\mathrm{~s}, 1 \mathrm{H}, \mathrm{CH}=\mathrm{N}) ; 7.25-7.5$ $(\mathrm{m}, 5 \mathrm{H}) ; 7.2(\mathrm{~d}, 1 \mathrm{H}, \mathrm{J}=6.8 \mathrm{~Hz}) ; 6.9-7.15(\mathrm{~m}, 4 \mathrm{H})$.

\subsection{Antiradical activity assessment}

The antiradical activity of compounds NIP, SIP, SIC, SIF, SIT and SIM was tested using DPPH scavenging activity, CUPRAC and reducing power assays. BHA and BHT were used as positive standards.

\subsubsection{DPPH scavenging activity method}

The free radical-scavenging activity was determined by the DPPH assay [10]. Briefly, $40 \mu \mathrm{L}$ of each sample solution prepared in ethanol at different concentrations was added to $160 \mu \mathrm{L}$ of a DPPH ethanolic solution $(0.1 \mathrm{mM})$. The mixture was left in darkness for $30 \mathrm{~min}$. The absorbance was measured at $517 \mathrm{~nm}$ using microplate reader. BHT and $\mathrm{BHA}$ were used as antioxidant standards. The results were given as $I C_{50}$ values $(\mu \mathrm{g} / \mathrm{mL})$ corresponding to the concentration of the compound capable of scavenging $50 \%$ of the initial DPPH. The scavenging percentage was calculated by using the formula:

Inhibition $(\%)=\frac{A_{\text {Sample }}-A_{\text {Control }}}{A_{\text {Sample }}} \times 100$

\subsubsection{Cupric reducing antioxidant capacity (CUPRAC) method}

The cupric reducing antioxidant capacity was determined according to Apak method [5]. In each well the reaction mixture containing $40 \mu \mathrm{L}$ of our sample, $50 \mu \mathrm{L}$ of copper (II) chloride solution, $50 \mu \mathrm{L}$ of neocuproine alcoholic solution and $60 \mu \mathrm{L}$ of ammonium acetate aqueous buffer at $\mathrm{pH} 7$. This mixture was left 30 min before measuring absorbance at $450 \mathrm{~nm}$. The results were expressed as $A_{0.50}$ values ( $\mu \mathrm{g} /$ $\mathrm{mL})$, corresponding to the sample concentration indicating 0.5 absorbance.

\subsubsection{Ferric reducing antioxidant power (FRAP) method}

Oyaizu's method [22] was used to estimate the reducing power activity of our compounds. $10 \mu \mathrm{L}$ of each sample solution at various concentrations were added to $40 \mu \mathrm{L}$ of $0.2 \mathrm{M}$ phosphate buffer $(\mathrm{pH} 6.6)$ and $50 \mu \mathrm{L}$ of potassium ferricyanide (1\%). Everything was incubated for 20 min at $50{ }^{\circ} \mathrm{C} .50 \mu \mathrm{L}$ of trichloroacetic acid (10\%) and $10 \mu \mathrm{L}$ of ferric chloride $(0.1 \%)$, was added to the mixture and completed with $40 \mu \mathrm{L}$ of distilled water. The ferric reducing antioxidant power was followed spectrophotometrically at $700 \mathrm{~nm}$, and the $A_{0.50}$ values $(\mu \mathrm{g} / \mathrm{mL})$ were calculated.

All data on antiradical activity test were the average of triplicate analyses. Data were recorded as the mean \pm standard deviation. Significant differences between means were determined using Student's t test; $p$ values $<0.05$ were regarded as significant.

\subsection{DFT calculations}

\subsubsection{Molecular modeling and geometry optimization}

Molecular structures of the six molecules and the corresponding charged and radical species $\left(\mathrm{RX}^{-}, \mathrm{RX}^{\circ}\right.$ and $\left.\mathrm{RX}-\mathrm{H}^{+^{\circ}}\right)$ were optimized by DFT using B3LYP functional with the 6-311G $(d, p)$ basis set. No geometrical constraints were applied. Frequency calculations were carried out by the same level of theory. Solvent effects were considered via the IEF-PCM salvation model [26]. Noting that a preliminary molecular dynamics study using Chem3D Ultra software (version 8.0) with the molecular mechanics force field MM2 was performed [(ChemOffice 2003, CambridgeSoft Corporation)].

\subsubsection{Descriptors calculation}

Molecular descriptors are calculated using Eqs. (1)-(5) at $298.15 \mathrm{~K}$ and 1 atmosphere. For this purpose, we need to know the enthalpy values of hydrogen atom $(\mathrm{H})$, proton $\left(\mathrm{H}^{+}\right)$and electron $\left(\mathrm{e}^{-}\right)$which are equal to $-1309.408 \mathrm{~kJ} /$ $\mathrm{mol}, 6.197 \mathrm{~kJ} / \mathrm{mol}$ and $3.145 \mathrm{~kJ} / \mathrm{mol}$, respectively, in the gas phase $[8,16]$. In ethanol, the value of $-1307.479 \mathrm{~kJ} / \mathrm{mol}$ was used for the hydrogen atom enthalpy [7] whereas, the enthalpies of proton and electron, $H\left(H_{\text {sol }}^{+}\right)$and $H\left(e_{\text {sol }}^{-}\right)$, were obtained from the corresponding solvation enthalpies [27] and were equal to $-1012.303 \mathrm{~kJ} / \mathrm{mol}$ and $-102.154 \mathrm{~kJ} / \mathrm{mol}$, respectively.

$$
\begin{aligned}
& B D E=H(R X)+H(H \cdot)-H(R X-H) \\
& I P=H\left((R X-H)^{+\cdot}\right)+H\left(e^{-}\right)-H(R X-H) \\
& P D E=H(R X)+H\left(H^{+}\right)-H\left((R X-H)^{+\cdot}\right) \\
& P A=H\left(R X^{-}\right)+H\left(H^{+}\right)-H(R X-H) \\
& E T E=H(R X)+H\left(e^{-}\right)-H\left(R X^{-}\right)
\end{aligned}
$$

\section{SN Applied Sciences}




\subsubsection{Frontier orbitals and spin-densities calculation}

The distribution of the frontier orbitals which are the highest occupied molecular orbital (HOMO) and the lowest unoccupied molecular orbital (LUMO) of the optimized molecular structures was established at the B3LYP/6-311G $(d, p)$ level of DFT calculation. Besides, radicals atoms spin densities were computed, using the unrestricted open shell level UB3LYP/6-311G(d,p), through the calculation of vibrational frequencies of the generated radicals $\mathrm{RX}$ and $\mathrm{RX}-\mathrm{H}^{+^{\circ}}$. It should be noted that no significant change was observed in the results obtained after geometry optimization of the latter.

\section{Results and discussion}

\subsection{Antiradical activity assessment}

Results of the three used methods are gathered in Table 1.

\subsubsection{DPPH scavenging activity method}

The NIP compound exhibited the highest activity $\left(\mathrm{IC}_{50}\right.$ : $3.81 \pm 0.26 \mu \mathrm{g} / \mathrm{mL}$ ) more than the standards $\mathrm{BHA}$ and BHT $\left(\mathrm{IC}_{50}: 6.14 \pm 0.41\right.$ and $12.99 \pm 0.41 \mu \mathrm{g} / \mathrm{mL}$, respectively) followed by SIP compound $\left(\mathrm{IC}_{50}: 6.59 \pm 0.37 \mu \mathrm{g} /\right.$ $\mathrm{mL}$ ) showing a better activity also, in comparison with standards.

Table 1 Antiradical assays (DPPH scavenging activity, CUPRAC and reducing power) results. The corresponding antioxidant standards values are mentioned

\begin{tabular}{llll}
\hline Molecule & \multicolumn{3}{l}{ Antiradical activity } \\
\cline { 2 - 4 } & $\begin{array}{lll}\text { DPPH assay } \\
\text { IC }\end{array}$ CUPRAC assay & \multicolumn{2}{l}{ Reducing power assay } \\
& $\mathrm{A}_{0.50}(\mu \mathrm{mL} / \mathrm{mL})$ & $\mathrm{A}_{0.50}(\mu \mathrm{g} / \mathrm{mL})$ \\
\hline NIP & $3.81 \pm 0.26$ & $3.09 \pm 0.08$ & $9.21 \pm 1.91$ \\
SIP & $6.59 \pm 0.37$ & $4.26 \pm 0.44$ & $10.37 \pm 1.07$ \\
SIC & $>200$ & $6.98 \pm 0.13$ & $>200$ \\
SIF & $>200$ & $4.29 \pm 0.23$ & $42.46 \pm 1.01$ \\
SIT & $>200$ & $126.22 \pm 10.36$ & $>200$ \\
SIM & NA & $20.02 \pm 2.34$ & $>200$ \\
BHA & $6.14 \pm 0.41$ & $5.35 \pm 0.71$ & $6.77 \pm 1.15$ \\
BHT & $12.99 \pm 0.41$ & $8.97 \pm 3.94$ & $5.39 \pm 0.91$ \\
\hline
\end{tabular}

NA: No absorbance

$A_{0.50}(\mu \mathrm{g} / \mathrm{mL})$ : Sample concentration indicating 0.5 absorbance $\mathrm{IC}_{50}(\mu \mathrm{g} / \mathrm{mL})$ : Sample concentration corresponding to $50 \%$ scavenging of initial DPPH

\subsubsection{Cupric reducing antioxidant capacity (CUPRAC) method}

The obtained results from the CUPRAC assay showed that NIP, SIP, SIF and SIC exhibited a better antiradical activity than the tested standards, with an $\mathrm{A}_{0.50}$ of $3.09 \pm 0.08 \mu \mathrm{g} / \mathrm{mL}, 4.26 \pm 0.44 \mu \mathrm{g} / \mathrm{mL}, 4.29 \pm 0.23 \mu \mathrm{g} / \mathrm{mL}$ and $6.98 \pm 0.13 \mu \mathrm{g} / \mathrm{mL}$, respectively. SIM and SIT have a relatively weak activity with an $A_{0.50}$ of $20.02 \pm 2.34 \mu \mathrm{g} / \mathrm{mL}$ and $126.22 \pm 10.36 \mu \mathrm{g} / \mathrm{mL}$, respectively.

\subsubsection{Ferric reducing antioxidant power (FRAP) method}

FRAP results showed that NIP and SIP have the best reducing power activity among the tested molecules with an $A_{0.5}$ of $9.21 \pm 1.91 \mu \mathrm{g} / \mathrm{mL}$ and $10.37 \pm 1.07 \mu \mathrm{g} / \mathrm{mL}$, respectively. SIF presents a less important activity. No significant activity was observed for SIC, SIT and SIM.

\subsection{Molecular descriptors calculation}

The comparison of the calculated molecular descriptors with the experimental results allows us to note the following facts: (1) For the DPPH scavenging assay, only the two phenylhydrazones (NIP and SIP) showed an antiradical activity. These molecules present two possibilities of hydrogen atom transfer to the DPPH molecule via one of the three possible mechanisms mentioned above. The first possibility concerns the hydrogen atom bound to the oxygen atom $(\mathrm{O}-\mathrm{H})$ while the second one is related to that connected to the nitrogen atom $(\mathrm{N}-\mathrm{H})$. Consider first the $\mathrm{O}-\mathrm{H}$ bond, we can observe that for both molecules in vacuum, the following sequence: $B D E>I P>P A$, is respected (Table 2), which favours a HAT mechanism. Whereas the SPLET mechanism is preferred for the two molecules in ethanol, since the three descriptors are ordered in the flowing manner: $\mathrm{PA}>\mathrm{BDE}>\mathrm{IP}$. Concerning the $\mathrm{N}-\mathrm{H}$ bond, the results in Table 3 show that the mechanism preference is the same as in the first case $(\mathrm{O}-\mathrm{H}$ bond). Then, when

Table 2 Molecular descriptors (BDE, IP, PDE, PA and ETE) values ( $\mathrm{kJ} /$ $\mathrm{mol}$ ) calculated in vacuum, for the tested molecules and standards

\begin{tabular}{lllrll}
\hline Molecule & BDE & IP & \multicolumn{1}{l}{ PDE } & PA & ETE \\
\hline NIP & 392.62 & 645.62 & 1065.73 & 1491.19 & 220.16 \\
SIP & 397.47 & 672.76 & 655.30 & 1512.01 & 204.20 \\
SIC & 361.84 & 649.78 & 1030.79 & 1446.91 & 233.67 \\
SIF & 428.73 & 685.98 & 1061.49 & 1510.98 & 236.49 \\
SIT & 381.68 & 721.60 & 978.81 & 1283.59 & 416.82 \\
SIM & 380.28 & 699.58 & 999.44 & 1440.52 & 258.50 \\
BHA & 363.39 & 717.91 & 926.50 & 1488.69 & 156.76 \\
BHT & 349.19 & 722.41 & 943.59 & 1461.39 & 204.61 \\
\hline
\end{tabular}


Table $3 \mathrm{~N}-\mathrm{H}$ bond's BDE and PA values $(\mathrm{kJ} / \mathrm{mol})$ calculated in vacuum and ethanol, for NIP and SIP

\begin{tabular}{|c|c|c|c|c|}
\hline \multirow[t]{2}{*}{ Molecule } & \multicolumn{2}{|l|}{$\mathrm{BDE}$} & \multicolumn{2}{|l|}{ PA } \\
\hline & Vacuum & Ethanol & Vacuum & Ethanol \\
\hline NIP & 320.82 & 330.25 & 1438.15 & 265.68 \\
\hline SIP & 328.32 & 337.68 & 1446.41 & 268.11 \\
\hline
\end{tabular}

Table 4 Molecular descriptors (BDE, IP, PDE, PA and ETE) values ( $\mathrm{kJ} /$ $\mathrm{mol}$ ) calculated in ethanol, for the tested molecules and standards

\begin{tabular}{lllrll}
\hline Molecule & BDE & IP & \multicolumn{1}{l}{ PDE } & PA & ETE \\
\hline NIP & 383.88 & 402.22 & 174.69 & 244.73 & 332.17 \\
SIP & 394.02 & 417.08 & 169.95 & 293.54 & 293.49 \\
SIC & 361.99 & 417.99 & 137.02 & 239.22 & 315.79 \\
SIF & 421.43 & 453.52 & 160.93 & 297.21 & 317.25 \\
SIT & 381.53 & 489.90 & 84.64 & 233.77 & 340.78 \\
SIM & 379.41 & 468.19 & 104.24 & 240.61 & 331.82 \\
BHA & 357.61 & 447.17 & 103.46 & 288.79 & 261.84 \\
BHT & 347.45 & 464.94 & 75.53 & 264.36 & 276.11 \\
\hline
\end{tabular}

comparing SIP and NIP PA values in ethanol phase, which was found to be the determinant descriptor in both cases, the $\mathrm{O}-\mathrm{H}$ bond proton departure was favourable in NIP; however the $\mathrm{N}-\mathrm{H}$ bond proton departure was favourable in SIP. Furthermore, it's known that the hydrogen atom of the $\mathrm{N}-\mathrm{H}$ bond is mostly more labile than that of the $\mathrm{O}-\mathrm{H}$ bond, because of their bonds strengths equal to $314 \pm 17 \mathrm{~kJ} / \mathrm{mol}$ and $428 \pm 2.1 \mathrm{~kJ} / \mathrm{mol}$ [29], respectively, but the existence of the electron attraction effect exerted by the phenyl group in NIP seems to weaken the $\mathrm{O}-\mathrm{H}$ bond and further makes its hydrogen-atom abstraction more favourable. If we make the same comparison in vacuum, but this time with $B D E$ values, we can see that the $\mathrm{N}-\mathrm{H}$ bond hydrogen departure is favourable for the two molecules. Hence, in all possible cases, NIP may have a better DPPH scavenging activity than SIP. In the other hand, the structural difference between SIP and the four azomethines lies in the substitution of the $\mathrm{NH}-\mathrm{Ph}$ group by other groups. This difference may be responsible for the loss of DPPH scavenging activity for our azomethines. This fact supports our hypothesis that the departure of
Fig. 2 SOMO isosurfaces plots of the six cation-radicals, calculated at UB3LYP/6-311G(d,p) level in ethanol phase. All of these plots are delocalized through the entire corresponding cation-radical

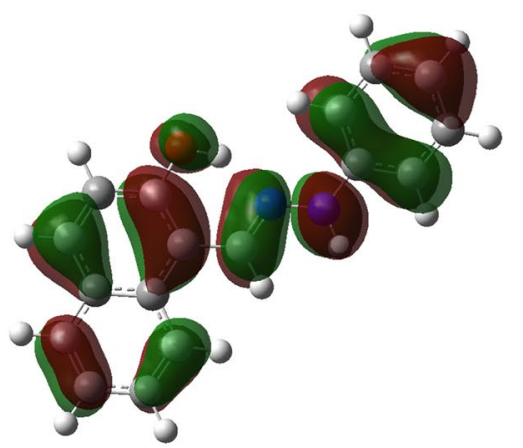

NIP

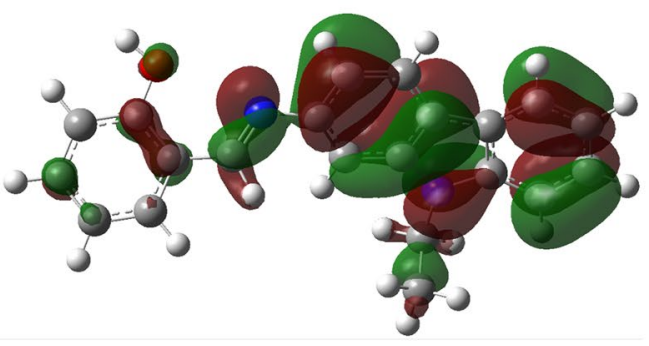

SIC
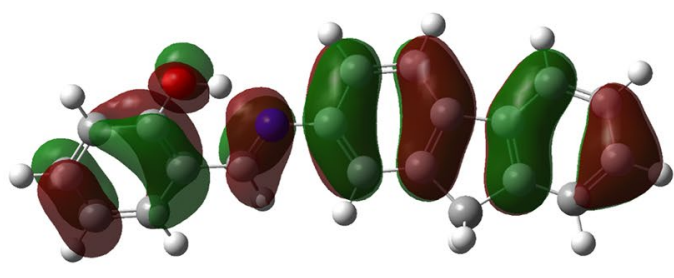

SIF

SIM

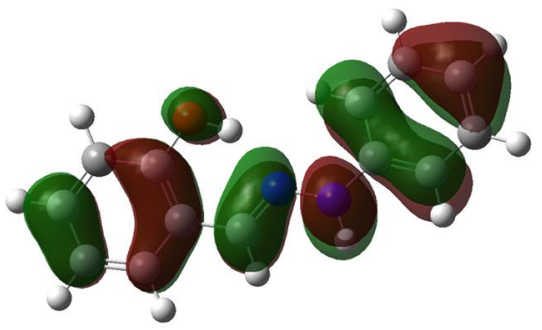

SIP
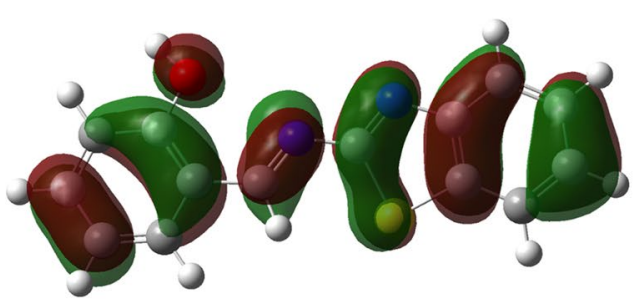

SIT 
Fig. 3 3D structures of the six cation-radicals, obtained at UB3LYP/6-311G(d,p) level in ethanol phase. Only NIP, SIF and SIP cation-radicals have an intramolecular hydrogen bond (dashed green line). The mentioned values in $\AA$ are obtained by means of the Discovery Studio 4.0 software [1]

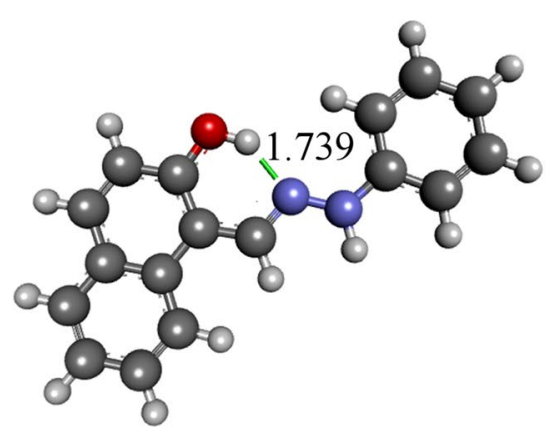

NIP

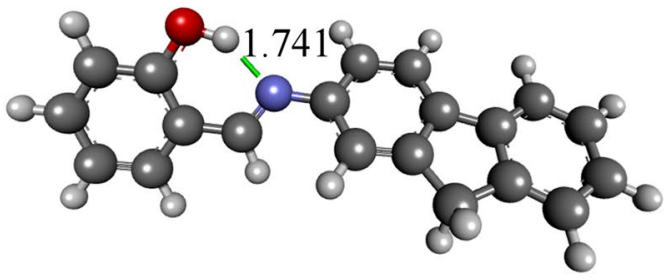

SIF

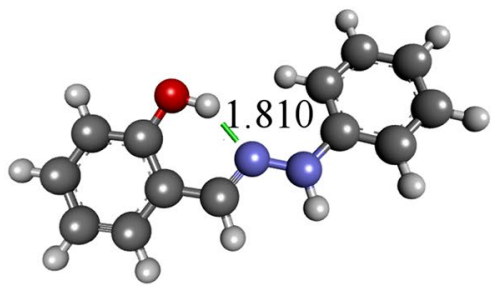

SIP
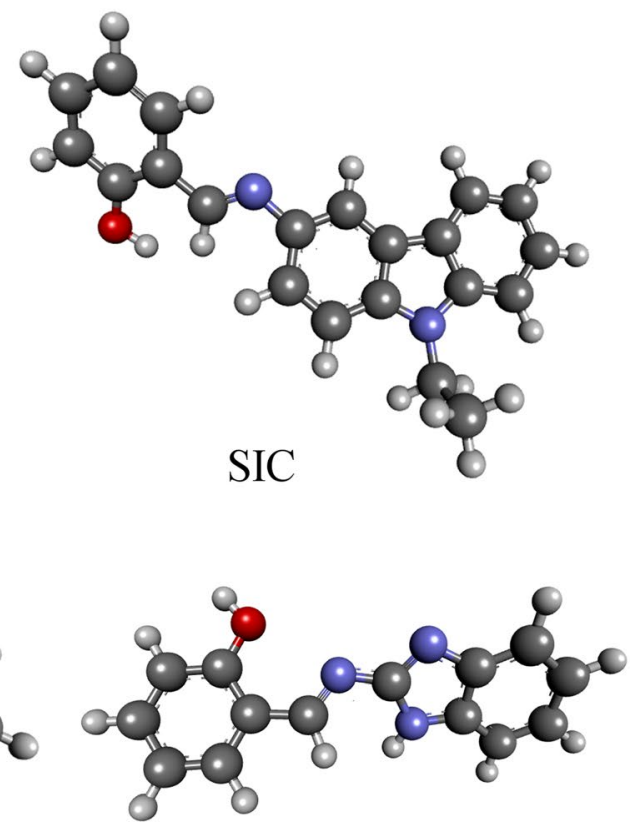

SIM

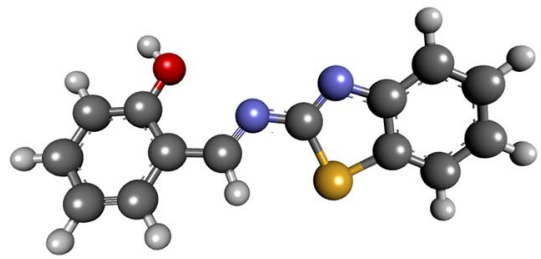

SIT the $\mathrm{N}-\mathrm{H}$ bond proton, in the case of SIP, is more favourable than that of the $\mathrm{O}-\mathrm{H}$ bond.

The comparison of the antioxidant standards (BHA and $\mathrm{BHT}$ ) descriptors with those of SIP and NIP shows that, the following order was observed in ethanol: $\mathrm{O}-\mathrm{H}$ $\mathrm{PA}$ of NIP $<\mathrm{N}-\mathrm{H}$ PA of SIP $<\mathrm{PA}$ of BHA $<\mathrm{BDE}$ of BHT. This result matches perfectly with the $\mathrm{IC}_{50}$ values of the DPPH assay (Table 1). Moreover, in vacuum we can note that $\mathrm{N}-\mathrm{H}$ BDE of NIP $<\mathrm{N}-\mathrm{H}$ BDE of SIP $<$ BDE of BHT $<$ BDE of BHA.

(ii) For the used electron transfer based tests, CUPRAC and reducing power, the order of antiradical activity, which is inversely proportional to the IP values of molecules, was: NIP $>$ SIP $>$ SIF $>$ SIC $>$ SIM $>$ SIT, for CUPRAC assay and NIP $>$ SIP $>$ SIF, for reducing power assay. Likewise, IP values in ethanol (Table 4) are ordered as follows: $\mathrm{SIT}>\mathrm{SIM}>\mathrm{SIF}>\mathrm{SIC}>\mathrm{SIP}>\mathrm{NIP}$ which constitute a nearly perfect agreement between the theoretical approach and experimental one.

\subsection{Frontier orbitals calculation}

HOMO energy ( $\left.E_{\text {HOMO }}\right)$ is also a revealing criterion of the reactivity between the corresponding molecule and DPPH, so that the electronic transfer is made from the highest $\mathrm{E}_{\mathrm{HOMO}}$ entity to the lowest one. Therefore, the electronic transfer is energetically unfavourable in the case where $\mathrm{E}_{\mathrm{HOMO}}$ of the DPPH is the highest. The calculated values of $\mathrm{E}_{\text {Hомо }}$ in ethanol are $-513.88 \mathrm{~kJ} / \mathrm{mol},-527.66 \mathrm{~kJ} / \mathrm{mol}$ and $-553.71 \mathrm{~kJ} / \mathrm{mol}$ for NIP, SIP and DPPH, respectively, which match well with the DPPH assay results. Concerning CUPRAC and reducing power assays, the electron donating is easier for a molecule that possesses a higher $\mathrm{E}_{\mathrm{HOMO}}$ [3]. The order of that energy values in ethanol, for the tested compounds is as flows: NIP $>$ SIP $>$ SIC $>$ SIF $>$ SIM $>$ SIT which is in a good accordance with experience.

Singly occupied molecular orbital (SOMO) isosurfaces of the six cation-radicals look to be homogeneously distributed which is a synonym of their stability (Fig. 2). Thus, the 

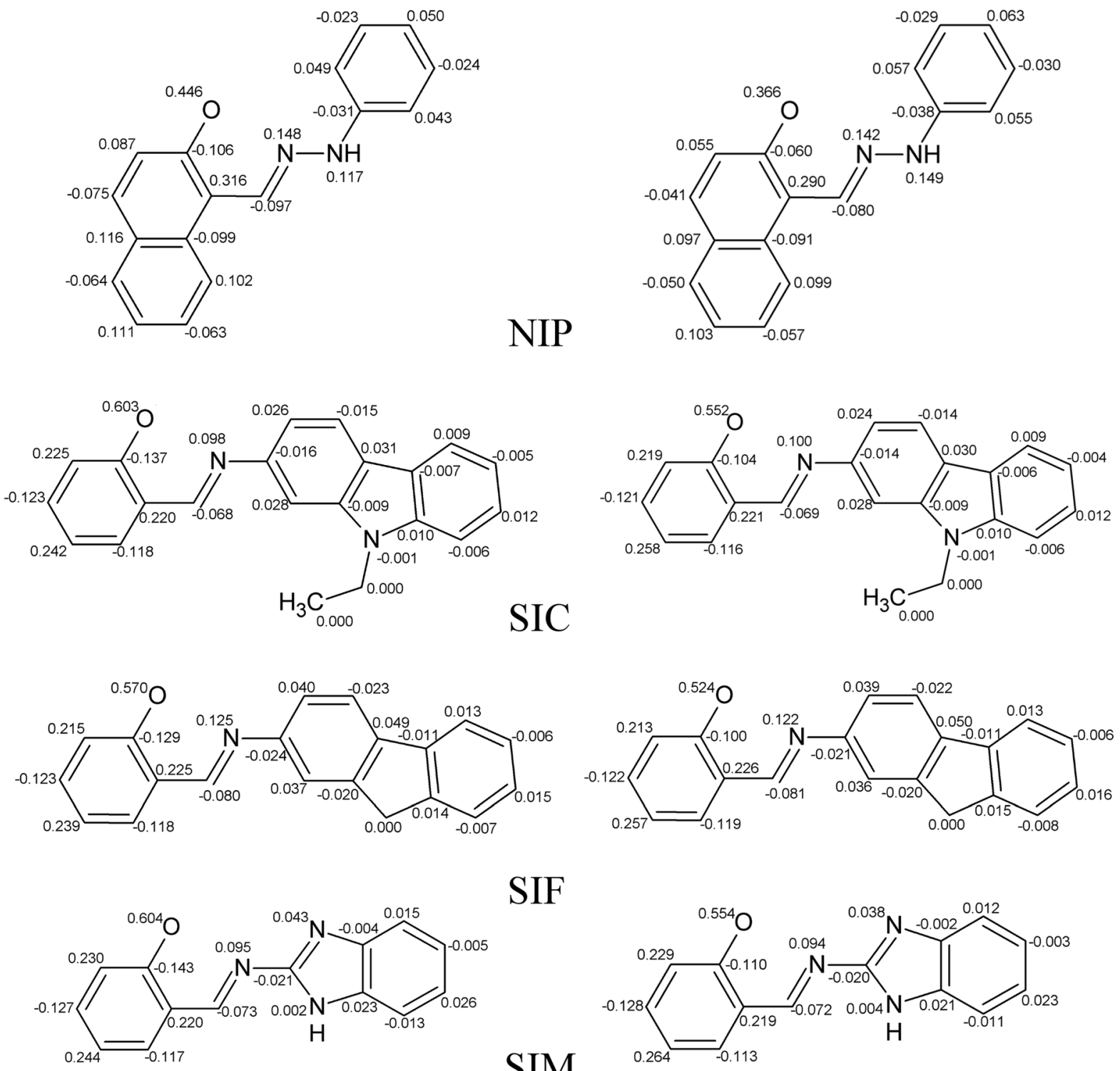

SIF

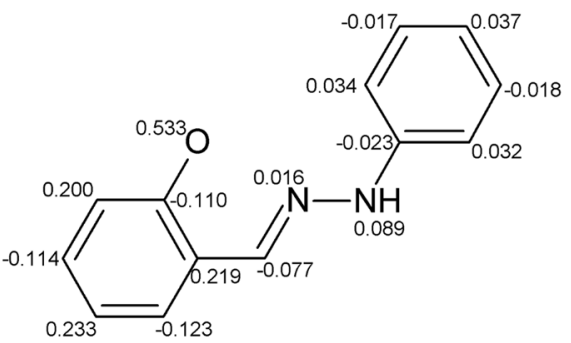

SIM

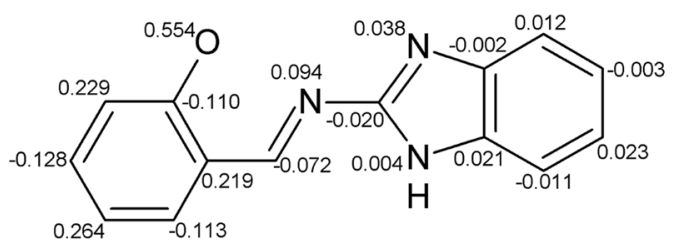

SIP
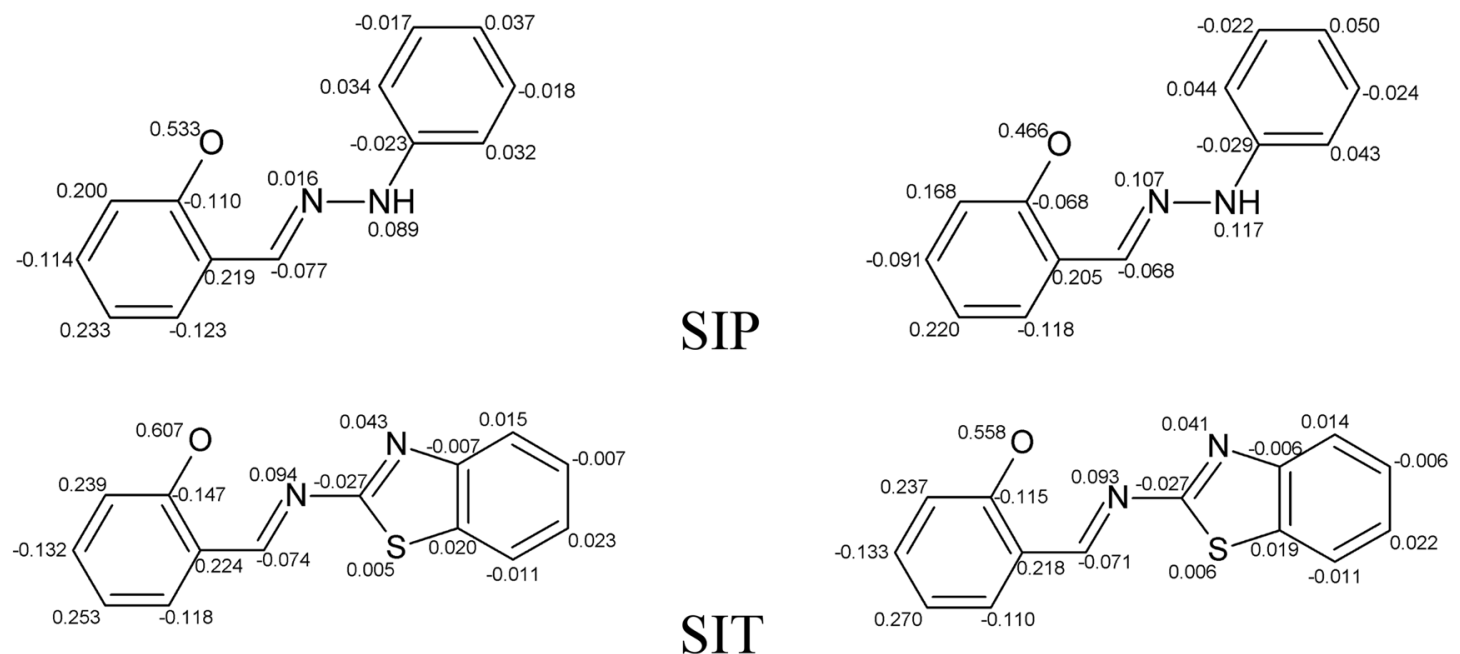

Fig. 4 Spin density distribution of the studied molecules, calculated in ethanol medium (right) and in gas phase (left), at UB3LYP/6$311 \mathrm{G}(\mathrm{d}, \mathrm{p})$ level 
electron-transfer is favourable for all of the corresponding neutral molecules. One other stabilizing factor for the three most active tested molecules (NIP, SIP and SIF) is the existence of an intramolecular hydrogen bonding interaction between the $\mathrm{O}-\mathrm{H}$ hydrogen atom and the nearest nitrogen atom (Fig. 3), which is noticeable in the bounding character of the SOMO distributions of the three molecules in this region (Fig. 2).

\subsection{Spin density}

Frequency calculation for radicals and cation-radicals were performed and no spin contamination was found. The comparison of the spin density distribution permits to evaluate the relative stability of molecules. The more the spin density is delocalized, the more the radical is stable and its formation is favourable. We can note that the highest value of spin density in each radical is localized on the hydroxyl oxygen atom. The lower is this value, the better the spin distribution is homogeneous. The lowest values are assigned to NIP and SIP, respectively, as we expected (Fig. 4). Moreover, for all the present molecules, this value is always lower in ethanol than in vacuum which means that the formed radicals are further stabilized by the solvent molecules, as reported in literature [30].

\section{Conclusion}

The obtained results from the used antiradical activity methods illustrate that NIP and SIP exhibited a good radicals scavenging power, even better than the customary used antioxidant standards. Besides, the most thermodynamically favorable DPPH scavenging mechanisms were investigated theoretically and the SPLET mechanism was suggested for both cited molecules, with a difference in the nature of the outgoing proton. The $\mathrm{O}-\mathrm{H}$ bond proton extraction is more favorable for NIP, whereas, the $\mathrm{N}-\mathrm{H}$ bond proton departure is more suitable, in the case of SIP. In the other hand, for CUPRAC and reducing power, the tested molecules were ordered as follows: "NIP $>$ SI $\mathrm{P}>\mathrm{SIF}>\mathrm{SIC}>\mathrm{SIM}>\mathrm{SIT}$ " and "NIP $>\mathrm{SIP}>\mathrm{SIF}$ ", respectively. These results are in excellent accordance with the calculated IP and $\mathrm{E}_{\text {Hомо }}$. Further, the existence of intramolecular hydrogen bonds for the cation-radical of the most active molecules NIP, SIP and SIF constitutes a stabilizing element for these radicals. Basing on the experimental and the theoretical parts of our study, we believe that with additional tests, our compounds can be useful to prevent products oxidation in pharmaceutical or in food industries.
Acknowledgements The authors are grateful to DGRSDT-MESRS (Algeria) for financial support.

\section{Compliance with ethical standards}

Conflict of interest On behalf of all authors, the corresponding author states that there is no conflict of interest.

\section{References}

1. Accelrys (2013) Discovery studio modeling environment, release 4.0. Accelrys software Inc., San Diego

2. Anouar EH, Raweh S, Bayach I, Taha M, Baharudin MS, Di Meo F, Hasan MH, Adam A, Ismail NH, Weber JF, Trouillas P (2013) Antioxidant properties of phenolic Schiff bases: structure-activity relationship and mechanism of action. J Comput Aided Mol Des 27(11):951-964

3. Antonczak S (2008) Electronic description of four flavonoids revisited by DFT method. J Mol Struct THEOCHEM 856(1-3):38-45

4. Apak R, Güçlü $K$, Demirata B, Özyürek $M$, Çelik SE, Bektaşoğlu B, Berker KI, Özyurt D (2007) Comparative evaluation of various total antioxidant capacity assays applied to phenolic compounds with the CUPRAC assay. Molecules 12(7):1496-1547

5. Apak R, Güçlü K, Özyürek M, Karademir SE (2004) Novel total antioxidant capacity index for dietary polyphenols and vitamins $C$ and $E$, using their cupric ion reducing capability in the presence of neocuproine: CUPRAC method. J Agric Food Chem 52(26):7970-7981

6. Arulmurugan S, Kavitha HP, Venkatraman BR (2010) Biological activities of Schiff base and its complexes: a review. Rasayan J Chem 3(3):385-410

7. Bamonti L, Hosoya T, Pirker KF, Böhmdorfer S, Mazzini F, Galli F, Netscher T, Rosenau T, Gille L (2013) Tocopheramines and tocotrienamines as antioxidants: ESR spectroscopy, rapid kinetics and DFT calculations. Bioorg Med Chem 21(17):5039-5046

8. Bartmess JE (1994) Thermodynamics of the electron and the proton. J Phys Chem 98(25):6420-6424

9. Baykara H, Ilhan S, Levent A, Seyitoglu MS, Özdemir S, Okumus V, Öztomsuk A, Cornejo M (2014) Synthesis, characterization and experimental, theoretical, electrochemical, antioxidant and antibacterial study of a new Schiff base and its complexes. Spectrochim Acta Part A 130:270-279

10. Blois MS (1958) Antioxidant determinations by the use of a stable free radical. Nature 81:1199-1200

11. Cheng LX, Tanga JJ, Luo H, Jin XL, Dai F, Yang J, Qian Y-P, Li $X Z$, Zhou B (2010) Antioxidant and antiproliferative activities of hydroxyl-substituted Schiff bases. Bioorg Med Chem Lett 20(8):2417-2420

12. Cozzi PG (2004) Metal-salen Schiff base complexes in catalysis: practical aspects. Chem Soc Rev 33:410-421

13. Dennington R, Keith TA, Millam JM (2016) GaussView, Version 5.0.9. Semichem Inc, Shawnee Mission, KS

14. Gaussian 09, Revision E.02, Frisch MJ, Trucks GW, Schlegel HB, Scuseria GE, Robb MA, Cheeseman JR, Scalmani G, Barone V, Petersson GA, Nakatsuji H, Li X, Caricato M, Marenich A, Bloino J, Janesko BG, Gomperts R, Mennucci B, Hratchian HP, Ortiz JV, Izmaylov AF, Sonnenberg JL, Williams-Young D, Ding F, Lipparini F, Egidi F, Goings J, Peng B, Petrone A, Henderson T, Ranasinghe D, Zakrzewski VG, Gao J, Rega N, Zheng G, Liang W, Hada M, 
Ehara M, Toyota K, Fukuda R, Hasegawa J, Ishida M, Nakajima T, Honda Y, Kitao O, Nakai H, Vreven T, Throssell K, Montgomery JA, Jr., Peralta JE, Ogliaro F, Bearpark M, Heyd JJ, Brothers E, Kudin KN, Staroverov VN, Keith T, Kobayashi R, Normand J, Raghavachari K, Rendell A, Burant JC, lyengar SS, Tomasi J, Cossi M, Millam JM, Klene M, Adamo C, Cammi R, Ochterski JW, Martin RL, Morokuma K, Farkas O, Foresman JB, Fox DJ, Gaussian Inc, Wallingford CT, 2016

15. Guergouri M, Bensegueni R, Khelifa Baghdouche A, Bencharif $L$ (2017) A comparative study of two different media effect on the electropolymerization of 2-(9-ethylcarbazol-3-yliminomethyl) phenol by cyclic voltammetry, impedance spectroscopy, xps, uv-visible measurements and dft calculation. Int Res J Pure Appl Chem 15(3):1-18

16. Jabbari M, Mir H, Kanaani A, Ajloo D (2014) Kinetic solvent effects on the reaction between flavonoid naringenin and 2,2-diphenyl-1-picrylhydrazyl radical in different aqueous solutions of ethanol: an experimental and theoretical study. J Mol Liq 196:381-391

17. Kumar GV, Khatoon BBA, Kumar KA (2015) Design and synthesis of novel pyrazolines as potent antimicrobial and antioxidant agents. J Chem Pharm Res 7(4):854-859

18. Langlois N, Dang TP, Kagan HB (1973) Synthèse asymetrique d'amines par hydrosilylation d'imines catalysée par un complexe chiral du rhodium. Tetrahedron Lett 14(49):4865-4868

19. Lee SA, You GR, Choi YW, Jo HY, Kim AR, Noh I, Kim SJ, Kim Y, Kim $C$ (2014) A new multifunctional Schiff base as a fluorescence sensor for $\mathrm{Al}^{3+}$ and a colorimetric sensor for $\mathrm{CN}^{-}$in aqueous media: an application to bioimaging. Dalton Trans 43:6650-6659

20. Leopoldini M, Russo N, Toscano M (2011) The molecular basis of working mechanism of natural polyphenolic antioxidants. Food Chem 125(2):288-306

21. Musialik M, Litwinienko G (2005) Scavenging of dpph• radicals by vitamin $E$ is accelerated by its partial ionization: the role of sequential proton loss electron transfer. Org Lett 7(22):4951-4954
22. Oyaizu M (1986) Studies on products of browning reactions: antioxidative activities of browning reaction prepared from glucosamine. Jpn J Nutr 44:307-315

23. Pânzariu $A$, Vasincu IM, Dragostin OM, Drăgan $M$, Buron $F$, Routier $S$, Profire $L$ (2015) New arginine derivatives-synthesis and biological evaluation. FARMACIA 63(4):581-585

24. Petrovic ZD, Dorovic J, Simijonovic D, Petrovic VP, Markovic Z (2015) Experimental and theoretical study of antioxidative properties of some salicylaldehyde and vanillic Schiff bases. RSC Adv 5:24094-24100

25. Tadele KT (2017) Antioxidant activity of Schiff bases and their metal complexes: a recent review. J Pharm Med Res 3(1):73-77

26. Tomasi J, Mennucci B, Cammi R (2005) Quantum mechanical continuum solvation models. Chem Rev 105(8):2999-3093

27. Tošović J, Marković S, Milenković D, Marković Z (2016) Solvation enthalpies and Gibbs energies of the proton and electron: influence of solvation models. J Serb Soc Comput Mech 10(2):66-76

28. Wang X, Chen YF, Yan W, Cao LL, Ye YH (2016) Synthesis and biological evaluation of benzimidazole phenylhydrazone derivatives as antifungal agents against phytopathogenic fungi. Molecules 21(11):1574-1587

29. Weast RC, Astle MJ (1980) Handbook of chemistry and physics CRC, 61st edn. CRC Press, Boca Raton

30. Xue Y, Zheng Y, An L, Dou Y, Liu Y (2014) Density functional theory study of the structure-antioxidant activity of polyphenolic deoxybenzoins. Food Chem 151:198-206

31. Yorur-Goreci C, Altas-Kiymaz N, Peksel A, Bilgin-Eran B, Sonmez $M$ (2014) New p-substituted salicylaldehyde phenylhydrazone derivatives synthesis, characterization, and antioxidant activities. Sci Pharm 82(4):735-747

32. Zaltariov MF, Rudic V, Rudi L, Chiriac T, Shova S, Vlada A, Cazacu $M$ (2015) Synthesis, characterization and evaluation of antioxidant activity of a new ferrocenyl-imine containing siloxane sequence. Rev Roum Chim 60(7):797-802 